\title{
IDENTIFIKASI RUMAH INDEKOS BERBASIS SYARIAH DI JALAN MENCO VII (PENEKANAN PADA POLA TATA RUANG)
}

\author{
Erlina Romdloni \\ Program Studi Arsitektur Fakultas Teknik \\ Universitas Muhammadiyah Surakarta \\ e-mail: erlinaromdloni@gmail.com

\section{Alpha Febela Priyatmono \\ Program Studi Arsitektur Fakultas Teknik Universitas Muhammadiyah Surakarta e-mail: alpha_febela@ums.ac.id}

\begin{abstract}
ABSTRAK
Dewasa ini rumah indekos telah berubah fungsi utamanya sebagai tempat tinggal menjadi sebuah industri indekos yang lebih berorientasi pada materi saja sehingga transformasi akan nilai-nilai yang ada dalam masyarakat cenderung terabaikan. Hal ini berakibat tidak menutup kemungkinan munculnya suatu perilaku menyimpang atau pelanggaran yang dilakukan oleh penghuni indekos, misalnya terjadi pergaulan bebas di lingkungan indekos. Universitas Muhammadiyah Surakarta yang merupakan kampus berbasis Islami memiliki tanggung jawab atas permasalahan yang ada di lingkungan sekitarnya, termasuk perilaku penyimpangan yang terjadi di kalangan civitas akademi. Tanggungjawab ini guna menghormati adab bermasyarakat dan menghasilkan generasi penerus bangsa yang baik. Permasalahan ini perlu diangkat untuk dicari penyebabnya, terutama sebab dari segi arsitektural, meliputi pola tata ruang yang berpengaruh pada kegiatan penghuni indekos dan Zonasi ruang indekos. Penelitian ini bertujuan untuk mengetahui indekos dengan konsep pola tata ruang syariah yang mengedepankan nilai-nilai Islam sehingga permasalahan yang terjadi bisa diminimalisir. Obyek penelitian dilakukan di Jalan Menco Raya dimana terdapat berbagai jenis rumah indekos untuk mahasiswa. Sampel diambil secara acak di Jalan Menco VII yang terdapat lima indekos khusus puteri. Metode penelitian menggunakan diskriptif kualitatif melalui teknik observasi dan wawancara. Hasil penelitian menemukan bahwa keberadaan zona public berupa ruang tamu, dapat meminimalisir terjadinya pergaulan bebas, karena tamu tidak dapat masuk ke kamar indekos (putri). Disamping penyelesaian arsitektural, keberadaan penjaga indekos sebagai elemen non-arsitektural penting juga untuk menjamin keamaan penghuni indekos.
\end{abstract}

KATA KUNCI: indekos; syariah; pola tata ruang, menco

\section{PENDAHULUAN}

Berdasarkan Undang-Undang Nomor 1 tahun 2011 permukiman adalah salah satu bentuk tanggung jawab negara untuk melindungi segenap bangsa Indonesia melalui penyelenggaraan perumahan dan kawasan permukiman, agar masyarakat mampu bertempat tinggal serta menghuni rumah yang layak dan terjangkau di dalam lingkungan yang sehat, aman, harmonis, dan berkelanjutan di seluruh wilayah Indonesia.

Rumah indekos adalah sebuah jasa yang menawarkan sebuah kamar atau tempat untuk ditinggali dengan sejumlah pembayaran pada periode tertentu. Rumah indekos biasanya terletak di area ramai seperti kampus, sekolah, maupun kawasan industri atau pabrik. Fungsi indekos sebagai hunian sementara ini yang menjadi pertimbangan bagi perantau karena menghemat biaya dan waktu karena tempat yang dekat dengan tujuan. Selain sebagai tempat tinggal juga sebagai wadah sosialisasi antar anak indekos. Seiring dengan banyaknya mahasiswa perantau dari luar daerah yang kuliah di Universitas Muhamamadiyah Surakarta (UMS), semakin banyak permintan (demand) rumah indekos.

Dewasa ini rumah indekos telah berubah fungsi utamanya sebagai tempat tinggal menjadi sebuah industri indekos yang lebih berorientasi pada materi saja sehingga transformasi akan nilai-nilai yang ada dalam masyarakat cenderung terabaikan sehingga tidak menutup kemungkinan munculnya suatu perilaku menyimpang atau pelanggaran yang dilakukan oleh anak indekos, misalnya terjadi pergaulan bebas antar lawan jenis di lingkungan rumah indekos.

Manfaat rumah tinggal akan optimal jika segala aktifitas keseharian manusia didasarkan pada ajaran Islam sehingga bernilai ibadah. Rumah dan lingkungannya seyogyanya didesain berdasarkan konsep Arsitektur Islam. (Nurhasan, Indrawati dan 
Islam, 2009). Permasalahan yang terjadi di area rumah indekos sekitar Universitas Muhammadiyah Surakarta adalah penyimpangan moral yang tidak sesuai dengan kaidah agama sehingga mengganggu ketentraman elemen masyarakat. Hal ini terjadi karena masih ada rumah indekos yang tidak menerapkan prinsip syariah, termasuk di dalamnya adalah rumah indekos yang terdiri dari laki-laki dan perempuan di dalam satu rumah. Hal ini dikhawatirkan akan terjadi hal-hal yang menyimpang dan kriminalitas. Penelitian ini mengambil sampel indekos di sepanjang Jalan Menco VII sekitar kampus UMS. Penelitian ini bertujuan mengidentifikasi rumah indekos berbasis syariah, semi syariah dan tidak syariah di Jalan Menco VII melalui parameter sederhana yaitu pola tata ruang yang teramati.

Manusia memiliki 3 kebutuhan primer yaitu sandang, pangan dan papan. Papan adalah tempat tinggal manusia untuk melakukan aktifitas vital, melangsungkan kehidupannya dan melindungi diri dari gangguan luar. Di dalam rumah dan lingkungannya itu, manusia akan terbentuk dan berkembang menjadi seseorang yang berkepribadian. (Juhana, 2000 : 31). Tempat tinggal dibagi menjadi dua jenis yaitu:

1. Hunian tetap;

Beragam bentuk dari hunian tetap seperti rumah pribadi dan apartemen yang bersetifikat hak milik.

2. Hunian sementara.

Hunian sementara seperti hotel, wisma, indekos, dan kontrakan yang sifatnya bayar sewa kepada penyedia layanan.

Rumah indekos biasanya dimiliki oleh penduduk setempat ataupun orang lain (bukan penduduk setempat) yang memiliki modal besar. Ada beberapa tipe rumah indekos bagi mahasiswa yaitu:

1. Berbentuk rumah keluarga yang didalamnya terdapat beberapa unit kamar dengan fasilitas ruang tamu, garasi, kamar mandi, hingga dapur bersama.

2. Berbentuk rumah bedeng atau bangunan yang memiliki banyak unit kamar berserta kamar mandi dalam. Dapur dan garasi umum. Tipologi ini biasanya tidak terdapat ruang khusus menerima tamu.

Syariah berasal dari bahasa arab yang artinya adalah jalan ke sebuah mata air yang harus diikuti. Secara terminologi arti Syariah adalah hukum-hukum yang ditetapkan oleh Allah SWT untuk hambahambanya yang dibawa oleh Nabi Muhammad SAW, baik berhubungan dengan tingkah laku maupun hukum-hukum furu'.

Arsitektur Islam adalah arsitektur yang berangkat dari konsep pemikiran Islam. Menurut (Nurjayanti, 2014) pendekatan nilai Islam sangat diperlukan untuk menemukenali karakter rumah tinggal islami. Karakteristik atau ciri-ciri rumah tinggal islami dapat ditemukan dari:

1. Aktivitas berdasarkan ibadah untuk mencari ridho Allah

2. Penzoningan berkonsep muhrim sesuai dengan struktur keluarga Islam

3. Tata ruang islami berkonsep akhlaq mulia

4. Seni islami berupa seni tauhid untuk mendekatkan diri dan mengingat Allah

Konsep perancangan rumah tinggal Islami diawali dengan mengelompokkan ruang-ruang dalam 3 kategori zonasi, yaitu :

1. Zona private, antara lain terdiri dari ruang tidur utama dan anak, ruang makan, pantry atau dapur bersih, ruang keluarga, wc dalam dan teras keluarga

2. Zona publik, terdiri dari ruang tamu dan teras tamu/teras depan

3. Zona service yang terdiri dari dapur, ruang pelayan, wc cuci, ruang cuci-jemur, ruang setrika dan garasi.

Indrawati (2007) menyebutkan bahwa konsep zonasi hunian islami yang berkaitan dengan pola tata ruang adalah :

1. Terdapat tiga kategori penzoningan ruang yaitu zona privat (terdiri dari ruang tidur, toilet, ruang makan), zona publik (terdiri dari ruang tamu, teras), dan zona servis (terdiri dari ruang cuci, jemur, dapur, garasi).

2. Ada penutup antara ruang privat dan publik sehingga privasi penghuni terjaga.

3. Letak tempat tidur membujur utara-selatan, supaya penghuni dapat tidur menghadap kiblat.

4. Peletakan kloset tidak menghadap kiblat.

5. Kamar mandi dan kloset berada pada ruang terpisah

6. Ruang tamu diletakkan di luar rumah (teras)

7. Terdapat hijab (penghalang) antara laki-laki dan perempuan (tidak bercampur)

8. Terdapat musholla / ruang sholat.

\section{METODE PENELITIAN}

Metode penelitian yang digunakan adalah metode deskriptif kualitatif. Metode ini berkaitan dengan pengumpulan data untuk memberikan gambaran atau penegasan suatu konsep atau gejala untuk menjawab pertanyaan-pertanyaan yang berhubungan dengan status subyek penelitian pada saat ini, misalnya sikap atau pendapat terhadap individu, organisasi, dan sebagainya. Penelitian kualitatif adalah penelitian tentang riset yang bersifat deskriptif dan cenderung menggunakan analisis dengan pendekatan induktif. Metode penelitian ini digunakan sebagai landasan peneliti dalam mengidentifikasi indekos berbasis syariah di Jalan Menco VII dengan pendekatan pola 
tata ruangnya. Variabel yang digunakan untuk mengidentifikasi indekos tersebut dalam kategori syariah, semi syariah, atau non-syariah sebagaimana Tabel 1.

Tabel 1. Penilaian Rumah Indekos Syariah

\begin{tabular}{lc}
\hline \multicolumn{1}{c}{ Kriteria Indekos Syariah } & Hasil \\
\hline $\begin{array}{l}\text { Terdapat tiga kategori penzoningan ruang } \\
\text { yaitu zona privat, zona publik, dan zona } \\
\text { servis. }\end{array}$ & $\mathrm{X}$ \\
\hline $\begin{array}{l}\text { Ada penutup antara ruang privat dan publik } \\
\text { sehingga privasi penghuni terjaga. }\end{array}$ & $\mathrm{X}$ \\
\hline $\begin{array}{l}\text { Terdapat hijab (penghalang) antara laki-laki } \\
\text { dan perempuan (tidak bercampur). }\end{array}$ & $\mathrm{X}$ \\
\hline Terdapat musholla/ ruang sholat. & $\mathrm{X}$ \\
\hline $\begin{array}{l}\text { Ruang tamu diletakkan di luar rumah } \\
\text { (teras) }\end{array}$ & $\mathrm{X}$ \\
\hline $\begin{array}{l}\text { Letak tempat tidur membujur utara- } \\
\text { selatan, supaya penghuni dapat tidur } \\
\text { menghadap kiblat. }\end{array}$ & $\mathrm{X}$ \\
\hline Peletakan kloset tidak menghadap kiblat. & $\mathrm{X}$ \\
\hline $\begin{array}{l}\text { Kamar mandidan kloset berada pada ruang } \\
\text { terpisah. }\end{array}$ & $\mathrm{X}$ \\
\hline
\end{tabular}

Penyajian data dalam bentuk tabel, lalu hasil di prosentase seberapa besar konsep tata ruang syariah yang diterapkan indekos tersebut. Perhitungan yang diterapkan sebagaimana prosentase yang tercantum pada rumus (1) :

$$
X=\frac{\mathrm{a}}{8} \times 100 \%
$$

Keterangan : $\mathrm{X}=$ hasil prosentase

$$
\mathrm{a}=\text { skor }
$$

Hasil penelitian dibagi menjadi 3 (tiga) parameter penilaian, yaitu :

1. Kategori Syariah dengan prosentase $\geq 75 \%$

2. Kategori Semi Syariah dengan Prosentase antara $30 \%$ sampai dengan $74 \%$

3. Kategori Non-Syariah dengan prosentase $<30 \%$ Pola pikir dan tahapan atau skematik penelitian yang digunakan dalam proses penelitian ini adalah sebagaimana Gambar 1 dan 2.

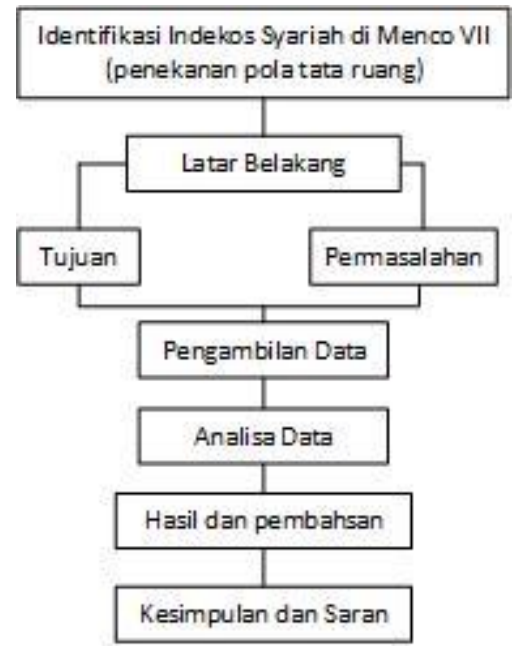

Gambar 1. Sitematika Penelitian

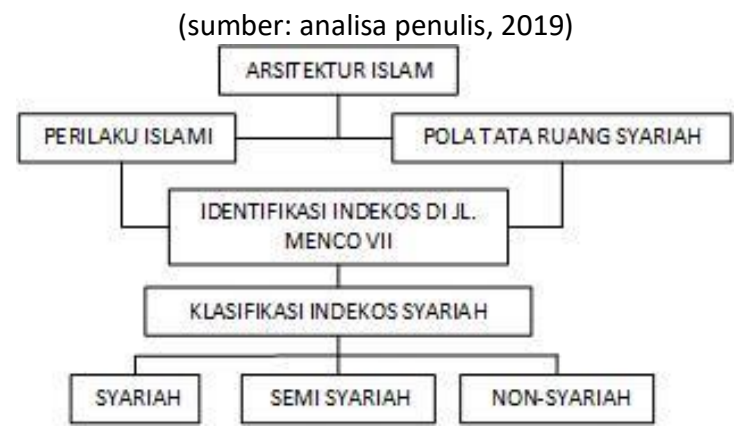

Gambar 2.Diagram Pola Pikir

(sumber: analisa penulis, 2019)

\section{HASIL DAN PEMBAHASAN}

\section{Analisis Data}

Berdasarkan data yang diperoleh dari hasil observasi lapangan dan wawancara, diketahui bahwa di Jalan Menco VII terdapat 5 rumah indekos yang semuanya adalah rumah indekos khusus putri. Denah rumah indekos dianalisis sesuai dengan kriteria rumah indekos syariah.

\section{Rumah Indekos Putri Ardelia (Indekos A)}

Rumah Indekos Ardelia adalah rumah indekos khusus putri yang mempunyai 18 unit rumah indekos yang disewakan dengan komposisi 8 unit di lantai 1 dan 10 unit di lantai 2, serta memiliki mushola di lantai 3. Semua unit rumah indekos dilengkapi dengan kamar mandi dalam. Zonasi ruang pada rumah indekos Ardelia yaitu terdiri dari :

a. Zona Privat (ruang tidur, toilet, ruang penjaga indekos)

b. Zona Publik (ruang tamu, balkon, teras, taman)

c. Zona Servis (dapur, musholla, ruang cuci + jemur)

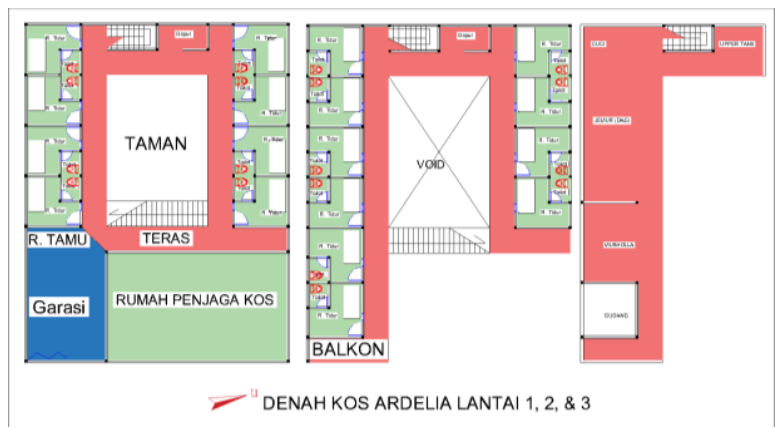

Gambar 3. Denah Indekos A

(sumber: dokumen penulis, 2019)

\begin{tabular}{|c|c|}
\hline Kriteria Rumah Indekos Syariah & Hasi \\
\hline $\begin{array}{l}\text { Terdapat tiga kategori penzoningan } \\
\text { ruang yaitu zona privat, zona publik, dan } \\
\text { zona servis. }\end{array}$ & $\checkmark$ \\
\hline
\end{tabular}

Tabel 2. Penilaian Rumah Indekos Ardelia 
Ada penutup antara ruang privat dan publik sehingga privasi penghuni terjaga.

Terdapat hijab (penghalang) antara laki-

laki dan perempuan (tidak bercampur).

\begin{tabular}{lc}
\hline Terdapat musholla/ ruang sholat. & $\checkmark$ \\
\hline $\begin{array}{l}\text { Ruang tamu diletakkan di luar rumah } \\
\text { (teras) }\end{array}$ & $\checkmark$ \\
\hline $\begin{array}{l}\text { Letak tempat tidur membujur utara- } \\
\text { selatan, supaya penghuni dapat tidur } \\
\text { menghadap kiblat. }\end{array}$ & $\mathrm{X}$ \\
\hline Peletakan kloset tidak menghadap kiblat. & $\checkmark$ \\
\hline $\begin{array}{l}\text { Kamar mandi dan kloset berada pada } \\
\text { ruang terpisah. }\end{array}$ & $\mathrm{X}$ \\
\hline
\end{tabular}

Nilai Prosentase :

$$
\begin{gathered}
X=\frac{6}{8} \times 100 \% \\
X=75 \%
\end{gathered}
$$

Prosentase syariah indekos Ardelia berdasarkan pola tata ruang adalah $75 \%$.

\section{Indekos Putri Beta (Indekos B)}

Indekos Beta adalah indekos khusus putri yang mempunyai 26 unit indekos yang disewakan dengan komposisi 9 unit di lantai 1 dan 17 unit di lantai 2 . Semua unit dilengkapi dengan kamar mandi dalam. Zonasi ruang pada indekos Beta yaitu terdiri dari :

a. Zona Privat (ruang tidur, toilet, ruang penjaga indekos)

b. Zona Publik (ruang tamu, teras)

c. Zona Servis (dapur, garasi, ruang cuci + jemur)

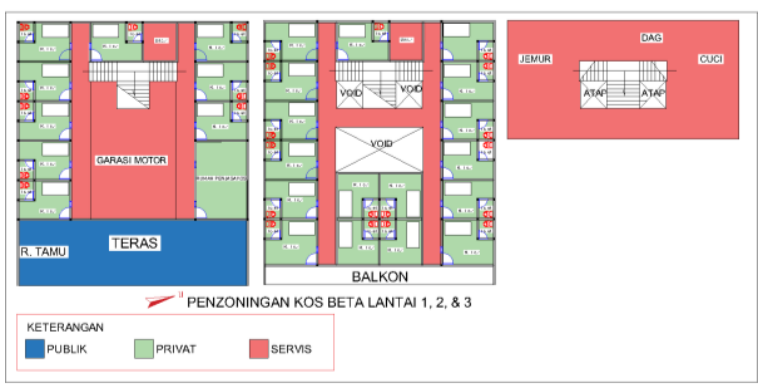

Gambar 4. Zonasi Indekos B

(sumber: analisa penulis, 2019)

Tabel 3. Penilaian Rumah Indekos Beta

\begin{tabular}{lc}
\multicolumn{1}{c}{ Kriteria Rumah Indekos Syariah } & Hasil \\
\hline Terdapat tiga kategori penzoningan & $\checkmark$ \\
ruang yaitu zona privat, zona publik, & \\
dan zona servis. & \\
\hline Ada penutup antara ruang privat dan & $\checkmark$ \\
publik sehingga privasi penghuni & \\
terjaga.
\end{tabular}

Terdapat hijab (penghalang) antara laki-laki dan perempuan (tidak

bercampur).

\begin{tabular}{ll}
\hline Terdapat musholla/ ruang sholat. & X \\
\hline $\begin{array}{l}\text { Ruang tamu diletakkan di luar rumah } \\
\text { (teras) }\end{array}$ & $\checkmark$ \\
\hline $\begin{array}{l}\text { Letak tempat tidur membujur utara- } \\
\text { selatan, supaya penghuni dapat tidur } \\
\text { menghadap kiblat. }\end{array}$ & $\checkmark$ \\
\hline $\begin{array}{l}\text { Peletakan kloset tidak menghadap } \\
\text { kiblat. }\end{array}$ & $\checkmark$ \\
\hline $\begin{array}{l}\text { Kamar mandi dan kloset berada pada } \\
\text { ruang terpisah. }\end{array}$ & $\mathrm{X}$ \\
\hline
\end{tabular}

Nilai Prosentase

$$
\begin{gathered}
X=\frac{6}{8} \times 100 \% \\
X=75 \%
\end{gathered}
$$

Prosentase syariah indekos Beta berdasarkan pola tata ruang adalah $75 \%$.

\section{Rumah Indekos Putri Ken Latip (Indekos C)}

Rumah Indekos Ken Latip adalah indekos khusus putri yang mempunyai 35 unit kamar indekos yang disewakan dengan komposisi 11 unit di lantai 1, 12 unit di lantai 2, 12 unit di lantai 3, dan dilengkapi ruang cuci + jemur di lantai 4 (atap). Semua unit dilengkapi dengan kamar mandi dalam. Zonasi ruang pada indekos Ken Latip yaitu terdiri dari :

a. Zona Privat (ruang tidur, toilet, ruang penjaga indekos)

b. Zona Publik (ruang tamu, teras)

c. Zona Servis (dapur, garasi, ruang cuci + jemur)
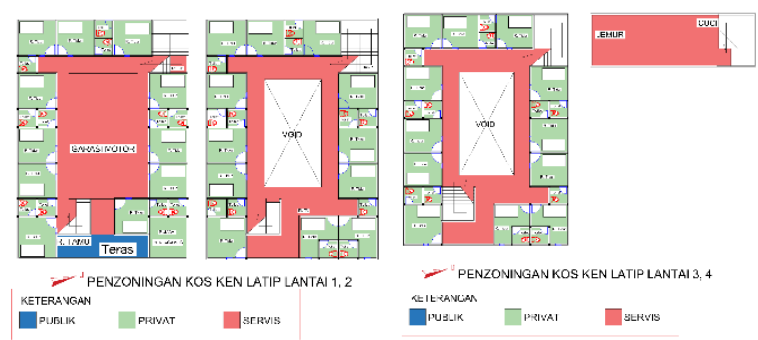

Gambar 5. Zonasi Indekos C

(sumber: analisa penulis, 2019)

Tabel 4. Penilaian Rumah Indekos Ken Latip

\begin{tabular}{lc}
\hline \multicolumn{1}{c}{ Kriteria Rumah Indekos Syariah } & Hasil \\
\hline $\begin{array}{l}\text { Terdapat tiga kategori penzoningan ruang } \\
\text { yaitu zona privat, zona publik, dan zona } \\
\text { servis. }\end{array}$ & $\checkmark$ \\
\hline $\begin{array}{l}\text { Ada penutup antara ruang privat dan publik } \\
\text { sehingga privasi penghuni terjaga. }\end{array}$ & $\checkmark$ \\
\hline $\begin{array}{l}\text { Terdapat hijab (penghalang) antara laki-laki } \\
\text { dan perempuan (tidak bercampur). }\end{array}$ & $\checkmark$ \\
\hline Terdapat musholla/ ruang sholat. & $\checkmark$ \\
\hline Ruang tamu diletakkan di luar rumah (teras) & $\checkmark$
\end{tabular}


Letak tempat tidur membujur utara-selatan,

$X$ supaya penghuni dapat tidur menghadap kiblat.

\begin{tabular}{lc}
\hline Peletakan kloset tidak menghadap kiblat. & $\checkmark$ \\
\hline Kamar mandi dan kloset berada pada ruang & $\mathrm{X}$
\end{tabular}
terpisah.

Nilai Prosentase :

$$
\begin{gathered}
X=\frac{6}{8} x 100 \% \\
X=75 \%
\end{gathered}
$$

Prosentase syariah indekos Ken Latip berdasarkan pola tata ruang adalah $75 \%$.

\section{Rumah Indekos Putri Pondok Alamo (Indekos}

D)

Rumah Indekos Pondok Alamo adalah indekos khusus putri yang mempunyai 10 unit kamar indekos yang disewakan dan dilengkapi ruang cuci + jemur. Indekos ini dilengkapi dengan fasilitas kamar mandi luar kamar. Zonasi ruang pada indekos Pondok Alamo yaitu terdiri dari :

a. Zona Privat (ruang tidur, toilet, ruang penjaga indekos)

b. Zona Publik (ruang tamu, teras)

c. Zona Servis (dapur, garasi, ruang cuci + jemur)

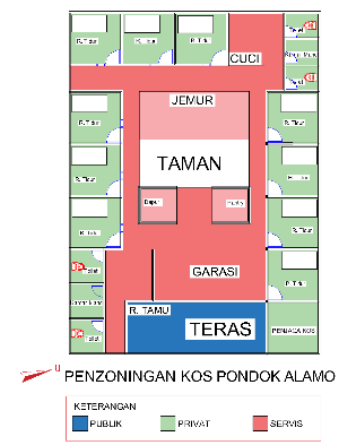

Gambar 6. Zonasi Indekos D

(sumber: analisa penulis, 2019)

Tabel 5. Penilaian Rumah Indekos Pondok Alamo

\begin{tabular}{lc}
\hline \multicolumn{1}{c}{ Kriteria Rumah Indekos Syariah } & Hasil \\
\hline $\begin{array}{l}\text { Terdapat tiga kategori penzoningan ruang } \\
\text { yaitu zona privat, zona publik, dan zona servis. }\end{array}$ & $\checkmark$ \\
\hline $\begin{array}{l}\text { Ada penutup antara ruang privat dan publik } \\
\text { sehingga privasi penghuni terjaga. }\end{array}$ & $\checkmark$ \\
\hline $\begin{array}{l}\text { Terdapat hijab (penghalang) antara laki-laki } \\
\text { dan perempuan (tidak bercampur). }\end{array}$ & $\checkmark$ \\
\hline Terdapat musholla/ ruang sholat. & $\checkmark$ \\
\hline Ruang tamu diletakkan di luar rumah (teras) & $\checkmark$ \\
\hline $\begin{array}{l}\text { Letak tempat tidur membujur utara-selatan, } \\
\text { supaya penghuni dapat tidur menghadap } \\
\text { kiblat. }\end{array}$ & $\mathrm{X}$ \\
\hline Peletakan kloset tidak menghadap kiblat. & $\checkmark$ \\
\hline $\begin{array}{l}\text { Kamar mandi dan kloset berada pada ruang } \\
\text { terpisah. }\end{array}$ & $\checkmark$ \\
\hline
\end{tabular}

$$
\begin{gathered}
X=\frac{7}{8} \times 100 \% \\
X=87,5 \%
\end{gathered}
$$

Prosentase syariah indekos Putri Pondok Alamo berdasarkan pola tata ruang adalah $87.5 \%$.

\section{Rumah Indekos Putri Afi (Indekos E)}

Rumah Indekos Afi adalah indekos khusus putri yang mempunyai 14 unit kamar indekos yang terdiri dari 6 unit di lantai 1 dan 8 unit di lantai 2 dan tambahan ruang cuci + jemur. Indekos ini dilengkapi dengan fasilitas kamar mandi dalam dan luar kamar. Zonasi ruang pada indekos Afi yaitu terdiri dari :

a. Zona Privat (ruang tidur, toilet, ruang penjaga indekos)

b. Zona Publik (ruang tamu, teras)

c. Zona Servis (dapur, garasi, ruang cuci + jemur)

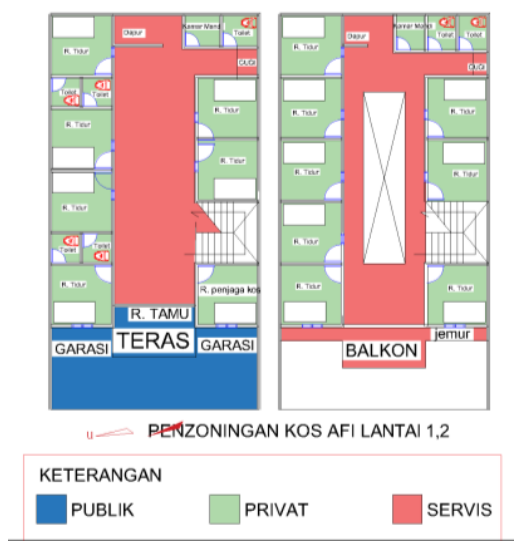

Gambar 7. Zonasi Indekos E

(sumber: analisa penulis, 2019)

Tabel 6. Penilaian Indekos Afi

\begin{tabular}{lc}
\hline \multicolumn{1}{c}{ Kriteria Indekos Syariah } & Hasil \\
\hline $\begin{array}{l}\text { Terdapat tiga kategori penzoningan ruang } \\
\text { yaitu zona privat, zona publik, dan zona } \\
\text { servis. }\end{array}$ & $\checkmark$ \\
\hline $\begin{array}{l}\text { Ada penutup antara ruang privat dan publik } \\
\text { sehingga privasi penghuni terjaga. }\end{array}$ & $\checkmark$ \\
\hline $\begin{array}{l}\text { Terdapat hijab (penghalang) antara laki-laki } \\
\text { dan perempuan (tidak bercampur). }\end{array}$ & $\checkmark$ \\
\hline Terdapat musholla/ ruang sholat. & $\checkmark$ \\
\hline Ruang tamu diletakkan di luar rumah (teras) & $\checkmark$ \\
\hline $\begin{array}{l}\text { Letak tempat tidur membujur utara-selatan, } \\
\text { supaya penghuni dapat tidur menghadap } \\
\text { kiblat. }\end{array}$ & $\mathrm{X}$ \\
\hline Peletakan kloset tidak menghadap kiblat. & $\checkmark$ \\
\hline $\begin{array}{l}\text { Kamar mandi dan kloset berada pada ruang } \\
\text { terpisah. }\end{array}$ & $\mathrm{X}$ \\
\hline
\end{tabular}

Nilai Prosentase : $\quad X=\frac{6}{8} \times 100 \%$

$X=75 \%$

Nilai Prosentase : 
Prosentase syariah indekos Putri Afi berdasarkan pola tata ruang adalah $75 \%$

\section{Pembahasan}

Hasil penelitian di beberapa rumah indekos diperoleh data prosentase syariah rumah indekos berdasarkan pola tata ruang dijelaskan dalam tabel 7 di bawah ini :

Tabel 7. Hasil Presentasi Rumah Indekos Syariah di Menco VII

\begin{tabular}{lc}
\hline \multicolumn{1}{c}{ Nama Rumah Indekos } & Presentase (\%) \\
\hline Rumah Indekos Ardelia (A) & 75 \\
\hline Rumah Indekos Beta (B) & 75 \\
\hline Rumah Indekos Ken Latip (C) & 75 \\
\hline $\begin{array}{l}\text { Rumah Indekos Pondok } \\
\text { Alamo (D) }\end{array}$ & 87.5 \\
\hline Rumah Indekos Afi (E) & 75 \\
\hline Rata-rata & 77.5 \\
\hline
\end{tabular}

Nilai rata-rata analisis indekos berbasis syariah di Menco VII dengan penekanan pola tata ruang $\geq 75 \%$, maka identifikasi indekos di Jalan Menco VII dengan penekanan pola tata ruang masuk klasifikasi indekos syariah.

\section{KESIMPULAN}

Hasil penelitian terhadap lima buah indekos putri di Jalan Menco VII adalah sebagai berikut:

1. Rumah indekos di Jalan Menco VII rata-rata telah memenuhi kriteria indekos berbasis syariah berdasarkan pola tata ruang. Nilainya mencapai $77.5 \%$

2. Zonasi ruang indekos di Menco VII sudah lengkap, namun beberapa masih samar antara zona publik dan zona servis, dimana tidak terdapat pembatas yang jelas.

3. Rumah indekos di Jalan Menco VII merupakan indekos khusus puteri sehingga tidak ada penghuni laki-laki dan indekos dijaga oleh penjaga indekos. Semua rumah indekos menerapkan ruang tamu di bagian teras sehingga relatif terhindar dari permasalahan yang dikhawatirkan yaitu pergaulan bebas antar lawan jenis, karena tamu laki-laki hanya berada di ruang tamu.

Berdasarkan pola tata ruang syariah, rumah indekos di Jalan Menco VII memenuhi standar syariah, namun ada beberapa hal penting untuk diperhatikan yaitu:

1. Ruang yang justru sangat penting yaitu musholla seringkali tidak terdapat di indekos-indekos tersebut. Padahal indekos khusus putri lebih baik menyediakan musholla di dalam rumah dikarenakan perempuan lebih baik sholat di rumah daripada ke masjid, seperti yang tertuang dalam sebuah riwayat :
Dari Ummu Salamah radhiyallahu 'anha, Rasulullah shallallahu 'alaihi wa sallam bersabda,

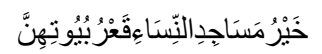

"Sebaik-baik masjid bagi para wanita adalah di bagian dalam rumah mereka." (HR. Ahmad, 6: 297. Syaikh Syu'aib Al-Arnauth mengatakan bahwa hadits ini hasan dengan berbagai penguatnya).

2. Zonasi ruang indekos perlu diperbaiki karena masih simpang siur dan tidak jelas alurnya. Pemahaman tentang toilet (kakus) dan kamar mandi yang dipisahkan ruangnya belum banyak diketahui oleh masyarakat.

\section{DAFTAR PUSTAKA}

Indrawati, dkk (2007) Metode Perancangan Rumah Dan Lingkungannya Berdasarkan Arsitektur Islam. Hibah Bersaing - Dikti tahun ke-5.

Juhana, Nasrudin. (2019). Metodologi Penelitian Pendidikan: Bandung: PT Panca Terra Firma.Buku Ajar Praktis Cara Membuat Penelitian.

Nurhasan, Indrawati, \& Islam, R. (2009). Metode Perancangan Rumah dan Lingkungannya Berdasarkan Arsitektur Islam. Hibah Penelitian Pekerti - Dikti, Universitas Muhammadiyah Surakarta.

Nurjayanti, Aly, \& Ronald, A. Karakteristik Rumah Tinggal dengan Pendekatan Islami. ISSN 14129612 Simposium Nasional RAPI XIII - 2014 FT UMS

Undang - Undang No.1 Tahun 2011 tentang Perumahan dan Kawasan Permukiman . 